\title{
EU citizenship and the categorization of EU migrants
}

T

he paper's aim is to underline the growing phenomenon of categorization of EU migrants despite the existence of a common EU citizenship. It addresses legal categorization deriving from EU legislation and the jurisprudence of the Court of Justice of the European Union, but also factual categorization arising from host member states' practices. The legal categorization of EU migrants reveals a clear differential treatment between economically active and inactive EU mobile citizens. Member states' practices very often go further than legal categorization by excluding poor mobile citizens, viewed as abusers of rights (benefit tourism) or as a potential threat to local public order or security (ill health, begging, violence). This paper also investigates the incompleteness of EU citizenship, being unable to prevent categorization of EU migrants.

The Freedom of MOVEMENT of EU citizens has undergone major changes since the beginning of the European project in the 1950s. Previously reserved exclusively for qualified workers, it enlarged slowly to other categories of nationals of the member states. But the recognition of an EU citizenship in 1992 certainly had the most emblematic impact on this fundamental right. EU citizenship was aimed at reassembling nationals of the member states under a common status, at providing common rights and obligations. While the right to freedom of movement was clearly priv- ileging economically active nationals, the conferral of an EU citizenship was totally independent of the economic status of the nationals of the member states. EU citizenship was, then, reinforcing the ongoing process of an extension of the personal scope of freedom of movement. Nevertheless, economically active and inactive EU migrants are today still not on the same footing. Indeed, EU citizenship does not prevent the differentiation of EU migrants, who are legally categorized according to different parameters such as the length of their stay or their economic situation. This categorization of EU migrants is primarily legal, as totally equal treatment has not been achieved yet, but it manifests itself also in the practice of host member states. Indeed, the last decade has shown more and more categorizations of EU migrants in member states' practices, following the occurrence of different economic, social and political challenges.

The aim of this paper is to show that notwithstanding past attempts to reduce the categorization of EU citizens on the move through the establishment of a European citizenship, as well as the gradual acquisition of more and more rights for economically inactive citizens, EU migrants are still today strongly categorized into different 
groups. Furthermore, this categorization seems to have been intensifying over the past decade. The first part of this article will review the relationship between EU citizenship and the fundamental right of freedom of movement of persons. The second part will address the legal categorization of EU migrants, while the third part will deal with member states' practices. Finally, the last part will underline the weaknesses of current EU citizenship, unable as it is to prevent the categorization of EU migrants.

\section{EU citizenship and freedom of movement of persons in the EU}

Since the beginning of its existence, EU citizenship has been very closely linked to the principle of freedom of movement and residence. These two rights share a common destiny as well as common beneficiaries.

\section{A shared destiny}

In 1992, a new concept emerged into the Maastricht Treaty, the EU citizenship which confers an additional citizenship to nationals of the member states. This new title unifies all the nationals of the member states under a common status. In fact, this new status is not just a title, it also brings new rights and new duties to nationals of EU member states. EU citizenship is inscribed into Article 20 TFEU $^{1}$ and

1 Article 20 TFEU (Treaty on the Functioning of the European Union): Citizenship of the Union is hereby established. Every person holding the nationality of a member state shall be a citizen of the Union. Citizenship of the Union shall be additional to and not replace national citizenship. Citizens of the Union shall enjoy the rights and be subject to the duties provided for in the Treaties. They shall have, inter alia: (1) the right to move and reside freely within the territory of the member states; (2) the right to vote and to stand as candidates in elections to the European Parliament and in
Article $9 \mathrm{TEU}^{2}$. The first right mentioned by Article 20 TFEU is the right to move and reside freely within the territory of the member states. And it is re-emphasized in the next Article 21 TFEU, which states that every citizen of the Union shall have the right to move and reside freely within the territory of the member states. The EU citizenship seems to find its best concretization in the freedom of movement and residence of EU citizens. Both EU citizenship and the right to freedom of movement are higher level rights. Indeed, EU citizenship is 'destined to become the fundamental status of nationals of the member states' according to numerous judgments of the Court of Justice of the European Union $(\mathrm{CJEU})^{3}$ and the right of freedom of movement has been recognized as a fundamental right ${ }^{4}$. EU citizens (Article 20) moving to another member state (Article 21) can

municipal elections in their member state of residence, under the same conditions as nationals of that State; (3) the right to enjoy, in the territory of a third country in which the member state of which they are nationals is not represented, the protection of the diplomatic and consular authorities of any member state on the same conditions as the nationals of that State; (4) the right to petition the European Parliament, to apply to the European Ombudsman, and to address the institutions and advisory bodies of the Union in any of the Treaty languages and to obtain a reply in the same language.

2 Article 9 TEU (Treaty on the European Union): In all its activities, the Union shall observe the principle of the equality of its citizens, who shall receive equal attention from its institutions, bodies, offices and agencies. Every national of a member state shall be a citizen of the Union. Citizenship of the Union shall be additional to and not replace national citizenship.

3 Case C-184/99 - Grzelczyk, paragraph 31.

4 Cases C-482/01 and C-493/01 - Orfanopoulos and Oliveri, paragraphs $97-8$; C-127/08 - Metock et al., paragraph 79. 
also rely upon another fundamental right; the right not to be discriminated against on the ground of nationality (Article 18 TFEU). All these three rights are closely linked and interrelated.

It is totally clear that EU citizenship and the freedom of movement of EU citizens are very closely linked, as these two rights are interconnected. But this close relationship goes far beyond the legal framework and reaches the EU citizens themselves. Freedom of movement is also the most favoured and tangible right of EU citizens (Flash Eurobarometer 365). Then, it is not surprising that the EU directive on freedom of movement and residence of EU citizens, Directive 2004/38/EC, has been called the 'Citizenship Directive.'

Although EU citizenship has undoubtedly played a key role into the success of the freedom of movement of EU citizens, this very close link has also been criticized, as EU citizenship is said to have mainly a transnational dimension. It is, in fact, much more useful for EU migrants abroad than for EU citizens staying at home. This prevalent cross-border aspect is often seen as excluding non-mobile EU citizens. That is why EU citizenship appears mainly as a 'citizenship of mobiles' (Shaw 2018: 5).

\section{Common beneficiaries}

EU citizens are the first beneficiaries of the right to move and reside within the territory of the member states. All the nationals

5 This title might seem misleading as it does not indicate that Directive 2004/38/EC also includes family members of the EU citizens, who might be third-country nationals and EEA citizens. Moreover, it is also quite confusing for readers, who are not freedom of movement experts as it might lead one to believe that the Directive deals with the acquisition of national or European citizenship. of EU member states can enjoy freedom of movement and residence, including:

- nationals of the 28 member states (older and new member states)

- outermost EU citizens from the 9 outermost regions of the EU: Guadeloupe, French Guiana, Réunion, Martinique, Mayotte and Saint-Martin (France), the Azores and Madeira (Portugal), and the Canary Islands (Spain).

- outermost citizens from certain overseas countries and territories associated to the EU, ex: New Caledonia, French Polynesia, Pitcairn, and Wallis and Futuna.

All these continental and outermost EU citizens can benefit from the fundamental right of freedom of movement that has also been enlarged to their family members (Articles 1 and 2, Directive 2004/38/ EC). EU citizenship unifies all nationals of the member states, notwithstanding their economic status (worker/non-worker), their ethnical status and number (majority/ minority) and their geographical position (continental/outermost). Thanks to EU Citizenship, different categories of nationals of member states are included in one category and enjoy the same legal status, the same rights at the European level, and are submitted to the same obligations.

Of course, not all EU citizens are enjoying their right to move, as some prefer staying at home. Similarly, EU citizens are not the only beneficiaries of the freedom of movement, as this right as been extended to the nationals of the European Economic Area (EEA). 


\section{Freedom of movement}

\section{and legal categorization of EU migrants}

The primary categorization of EU migrants is legal, as the right to move and stay derives from EU legislation that does not provide yet for equality of treatment for all movers. This right has nevertheless known different waves of categorization or attempts at unification of EU migrants. It is possible to distinguish three main periods that illustrate attempts of categorization or unification of EU migrants: from 1950 to 1991 (clear categorization of EU migrants), from 1992 to 2010 (visible but incomplete attempts at unification) and finally, since 2010 (recategorization of EU migrants).

\section{From 1950 to 1991: categorization of migrants by EU secondary legislation}

The 1950s, which saw the adoption of the Treaties of Rome and Paris, correspond to the beginning of the European project. Both of the aforementioned treaties contain the very first provisions on freedom of movement of nationals of the member states. These provisions are reserved to one category of nationals; economically active migrants including workers and selfemployed persons. But from 1968, the right to move and stay began to include economically inactive nationals, as national workers were then allowed to be accompanied by their family members. ${ }^{6}$ It was the first opening of an exclusive club, confirmed later by the right to remain in their host member state for former workers on the move who had lost their job abroad. ${ }^{7}$ This extension

6 Council Directive 68/360/EEC of 15.10 . 1968 on the abolition of restrictions on movement and residence within the Community for workers of member states and their families.

7 Council Directive 90/365/EEC on the right of residence for employees and self- continued in the 1990 s with the adoption of numerous directives regulating, category by category, the stay of economically inactive migrants. One directive regulated the stay of students, ${ }^{8}$ another targeted pension$\mathrm{ers}^{9}$ and yet another the other economically inactive migrants. ${ }^{10}$ The adoption of different legal instruments for each category of migrants illustrates well the process of categorization of EU migrants.

\section{From 1992 to 2010: between categorization} and attempts at unification of EU migrants

This period witnesses various attempts at unification of EU migrants, that have been made possible thanks to the emergence of a European citizenship, to the adoption of the so-called Citizenship Directive and to a generous approach of the jurisprudence of the CJEU. Nevertheless, equal treatment for EU migrants is far from being achieved.

By the time of the birth of EU citizenship in 1992, freedom of movement of nationals of member states had already reached a good standard. This fundamental right was no longer reserved to economically active migrants but had slowly been enlarged to include their family members, former workers and other categories of economically inactive migrants. At that time, the stay of EU migrants was organized category by category. The conferral of an EU citizenship was then very promising as Article 20 TFEU placed on the same footing all nationals of the member states,

employed persons who have ceased their occupational activities.

8 Council Directive 90/366/EEC of 28.6 .1990 on the right of residence for students.

9 Council Directive 90/365/EEC of 28.6 .1990 on the right of residence for employees and self-employed persons who have ceased their occupational activity.

10 Council Directive 90/364/EEC of 28.6 .1990 on the right of residence. 
without regard to their economic and social status.

The second step in this process of unification was certainly the adoption of Directive 2004/38/EC on the right of citizens of the Union and their family members to move and reside freely within the territory comprising the member states. This legal instrument serves as a kind of administrative unification: EU economically active and non-active citizens are no longer separate; their rights are governed in one single legal document. Indeed, Directive 2004/38/EC replaces all previous directives which divided EU citizens into different categories. Of course, this administrative unification is a merely theoretical unification as Directive 2004/38/EC does not treat equally economically inactive and active EU migrants. Indeed, Article 24 of Directive 2004/38/EC clearly provides different rights for these two categories of migrants:

- only workers and permanent residents benefit from equality of treatment;

- economically inactive migrants have conditional rights to residence and access to social assistance.

Moreover, Directive 2004/38/EC differentiates EU migrants according to the length of their stays. Indeed, administrative requirements necessary for residency within the territory of another member state will vary according to the length of the stay. Short-term residencies for a stay of less than three months are possible only upon the possession of a valid ID or passport, while long-term residency requires either the possession of sufficient financial resources and of a comprehensive sickness insurance (Article 7 for stays longer than three months) or five years of legal residency (Article 16 for permanent residence). Similarly, the sanctions applicable to EU migrants who are breaching their legal obligations will also vary according to the length of the stay. The longer the residence and thus the integration of the EU migrant, the more difficult will be the termination of his/her stay. So, Article 28 does not allow expulsion of long-term EU migrants on the ground of threat to public policy or public health while such grounds can be used against short-term stayers. Only serious grounds of public policy or public security, or imperative grounds of public security can be used against long stayers.

The third step in this process of unification of EU migrants was the adoption of a positive and generous approach by the CJEU. This approach was positive as it aimed to counterbalance EU restrictive legislation by opting for the most favourable provision for EU migrants. It was also generous towards economically inactive EU citizens as the Court was working towards the extension of their rights. The Court was using EU citizenship as a justification for the attribution of rights. It was considering that economically inactive nationals (students and job seekers) of EU member states were deserving of social rights because of their EU citizenship. Therefore, they could rely on the solidarity and generosity of the host member state. Financial solidarity and EU citizenship were then the leitmotiv in matters of internal migration. Later on, the CJEU moved towards taking a more compromising approach towards economically inactive nationals. They were still deserving of social rights based on their EU citizenship but only if they were not becoming an unreasonable burden on the social security system of the host member state. The generosity of the CJEU became conditional, probably under the pressure of new challenges affecting the European countries.

Unfortunately, this period of attempting to balance the status of EU economically 
active and non-active migrants has ended with the occurrence of different economic, social and political challenges. The enlargement of the EU to include the Central Eastern European Countries (CEECs) followed by a crisis in financial issues and migration has indeed placed heavy stress on the host member states, which began to fear for the integrity of their national budgets as well as their public policies and security. That is why the coming period will move more towards the reinforcement of the differentiation between active and nonactive EU migrants.

\section{From 2010:}

\section{the recategorization of EU migrants}

The process of recategorization of $\mathrm{EU}$ migrants is mainly visible in the recent jurisprudence of the CJEU. Indeed, since 2013, the CJEU has taken a series of decisions restricting access to social assistance for economically inactive migrants within the EU. This reversal of jurisprudence is aiming to combat potential abuses of social assistance by EU migrants. Different categories of economically inactive migrants have been targeted:

- In its case C-333/13, the CJEU stated that economically inactive Union citizens who go to another member state solely in order to obtain social assistance may be excluded from certain social benefits. Benefit or welfare tourists were clearly excluded from the generosity of the host member states. ${ }^{11}$

- In its case C-67/14, the CJEU stated that a member state may exclude Union citizens who go to that state to find work from receiving certain non-contributory social security benefits. Here, job

11 Case C-333/13 - Dano. seekers were being prevented from abusing social assistance. ${ }^{12}$

- In its case C-299/14, the CJEU confirmed that nationals of other member states may be refused certain social benefits in their first three months of residence. Here, short-term residents are excluded from the conferral of social assistance. ${ }^{13}$

- Finally, in its case C-308/14 (Commission $\mathrm{v}$ UK), the CJEU stated that the UK can require recipients of child benefit and child tax credit to have the right to reside in the UK. Although that condition is considered to amount to indirect indiscrimination, it is justified by the need to protect the finances of the host member state. Here, financial interests of the host member state clearly takes precedence over solidarity towards EU migrants. ${ }^{14}$

Through its recent decisions, the CJEU has allowed member states to apply restrictive measures to different categories of economically inactive EU citizens. The future might bring new decisions targeting other categories of economically inactive EU migrants such as students and retired persons. Indeed, many students have already been expelled from their host member states upon the ground of their lack of self-sufficiency. This recent reversal of the jurisprudence of the CJEU should not be taken lightly for various reasons. A study from the Centre for Migration Law of the University of Nijmegen has shown that the recent CJEU jurisprudence has already had a direct impact on the national case-law or legislation of certain member states, namely Germany, but also Portugal, Ireland, Malta,

12 Case C-67/14 - Alimanovic.

13 Case C-299/14 - García-Nieto.

14 Case C-308/14 - Commission v. UK. 
the Netherlands, Finland, Austria and the UK (Minderhoud 2018: 7). It is also used by some member states to justify restrictive national measures against economically inactive EU citizens on the move. Last but not the least, one should not forget that many decisions of the CJEU regarding freedom of movement of persons have been later codified into European legislation.

Besides the recategorization of $\mathrm{EU}$ migrants by the CJEU, there is a second demonstration of an attempt at a recategorization of EU migrants clearly visible in member states' practices and claims.

\section{Freedom of movement and member states' categorization of EU migrants}

Member states' practices show a clear will to categorize EU migrants into two categories: those who are the welcome (workers, self-sufficient, permanent residents, not belonging to a poor minority) and those who are not welcome (economically inactive, non-self-sufficient, belonging to a poor minority like the Roma community). The vocabulary used by some scholars to designate the treatment of this second category of migrants speaks for itself: 'underclass' (Lhernould 2011: 115), 'illegitimate' (Lafleur 2017: 219), 'bad' (Azoulai 2014: 13-15), 'abnormal' (Carrera 2014: 32-61) EU migrants.

The undesirable migrants are viewed as a threat to national public policy or security and as potential abusers of social assistance. This mistrust of the goodwill of EU migrants has led to the imposition of restrictions on the part of host member states in the area of freedom of movement of EU citizens.

\section{Member states' reluctance to welcome all EU citizens}

After the enlargement of the EU to the CEECs some of the oldest member states, anxious about a potential massive migration of poor Eastern citizens, decided to limit access to their national job markets. They used the so-called transitional arrangements. Only migrant workers from fields that would not prejudice the host member states were welcomed.

Later, the global economic crisis concomitant to the subsequent enlargements of the EU into the poorest countries such as Romania and Bulgaria gave rise to even more anxiety on the part of the oldest and richer member states. Fearing that their national budgets would be endangered by a massive influx of benefit tourists, some member states even addressed an official complaint to the European Commission. They declared the use of the right of freedom of movement to be fraudulent in this case and called for more restrictions towards the abusers of rights (Joint letter 2013). Clearly, economically inactive migrants were not welcome as the growing number of expulsions over the past decade clearly illustrates.

The non-self-sufficiency and the poverty of certain EU migrants are the subject of more and more anxiety for the host member states, who fear for the integrity of their national budgets. Beggars and homeless migrants are not welcome and are viewed as a threat to local public order. They are seen as potential offenders (through theft, illegal occupation of public land, prostitution, violence and so on). Host member states tend to deny the poorest EU migrants the right of freedom of movement, even if their lack of self-sufficiency makes them ineligible for social assistance. Their extreme and visible poverty seems to be sufficient reason to problematise them.

Besides this economic categorization of EU migrants, there is also a kind of 'ethnic categorization' of EU movers 
(Carrera 2014: 55). ${ }^{15}$ Indeed, EU citizens of Roma origin are certainly the most feared migrants by their host member states, but also sometimes by the local population. They accumulate a variety of parameters that make them non-welcome: first, they very often belong to the poorest category of EU migrants (non-self-sufficiency, extreme poverty) and secondly, their habits and traditions are said to impede any integration into the host country. ${ }^{16}$ Finally, they suffer from discrimination, institutional racism ${ }^{17}$ and sometimes from hate (The Conversation 2019), which leads to them being considered almost automatically as offenders against the law, as shown by recent sad events in France. Indeed, between 25 March and 9 April 2019, 25 attacks against Roma people were recorded in France after rumours spread on social media alleging that Roma people in a 'white van' were abducting children and planned

15 Sergio Carrera talks of an ethnicization of European Citizenship.

16 'In the specific case of Travelers caravan dwellers, their simple refusal to move into houses is viewed as evidence of an inability to conform to social norms as well as to contribute in any meaningful way to society' (Parnell-Berry and Lawton 2018: 53). Even Roma, who are not caravan travellers are sometimes seen as uncapable of integration as it was underlined by the French Minister of Interior, Manuel Valls: 'Les Roms nont pas vocation à s'intégrer, mais à rentrer dans leur pays' ('The Roma are not intended to integrate, but to return to their country'). LaLibre.be, 2013.

17 The European Court of Human Rights did, for the first time in April 2019, recognize that Roma communities are often confronted with institutionalized racism and are prone to excessive use of force by the law-enforcement authorities (ERRC 2019: 1-2). In May 2019, unprecedented police action against the Roma travellers community in Belgium has also occurred according to the ERGO Network. to rape them or sell their organs (ERGO Network 2019).

\section{Member states' factual categorization of EU migrants}

This de facto categorization, which is not grounded in any legal provision, differentiates EU migrants into two categories: the 'good' migrants and the 'bad' migrants.

\section{'Good' mobile EU citizens}

In practice, only workers are welcome. They don't represent a danger to the local national social security system as they are self-sufficient. And they are likely not to be a threat to public policy or security as they are busy working. But it seems that some workers are less welcome than others, as the adoption of transitional arrangements for CEEC nationals showed. Indeed, workers who could endanger the local job market such as the Polish plumber in France or the Polish butcher in the UK, are not welcome. Similarly, during the Brexit referendum, $\mathrm{Mr}$ Cameron was planning to exclude from social assistance workers who had been living in the UK less than four years. Here, the parameter of the length of the stay was aiming to differentiate economically active migrants. Social assistance should be reserved only for long-term workers.

\section{'Bad' mobile EU citizens}

'Bad' mobile EU citizens are those who are economically inactive. EU law allows the stay of economically inactive migrants as far as they are self-sufficient, and they do not become an unreasonable burden on the social security system. Host member states are often more severe. Economically inactive mobile EU citizens are viewed as potential abusers of social assistance and as a threat to public policy and security. To be sure to eliminate potential abusers, they often take national preventive measures to 
make access to social assistance very difficult. These self-defence provisions against welfare tourists can take different forms such as language tests or various residency tests. They don't hesitate also to expel nonself-sufficient EU citizens on the grounds of being an unreasonable burden, a threat to public policy or an abuser of social assistance, without respecting the material and procedural safeguards protecting EU citizens (Maslowski 2015: 67-70).

\section{The incompleteness of EU citizenship}

EU citizenship, whose objective is to bring together under a common status nationals of the member states seems today to be powerless in the face of such categorizations, mainly because of the incompleteness of its own status. Its edification as the fundamental status of nationals of the member states ${ }^{18}$ was supposed to erase the differential treatment between inactive and active EU citizens. Similarly, its use by the CJEU as the major criterion for the determination of social rights for economically inactive EU citizens seemed at one time promising, but did not weather the global economic crisis. Indeed, most of the time the reasons for differentiating between economically active and non-active EU movers are financial considerations. Nevertheless, its brief period of hope and glory allowed some to believe in European citizenship as a unique status for nationals of $\mathrm{EU}$ member states (Gastaldi 2013: 630). Two approaches to, and visions of, EU citizenship are in fact at stake: the first, deriving from EU law, is a consideration of EU citizenship 'by categories' and privileges EU migrants who are, or who were, workers. The second vision, based on the jurisprudence of the CJEU, encapsulates EU citi-

18 Case C-184/99 - Grzechyk. zenship as 'a unique status for all nationals of EU member states', willing to establish a unique and common system of protection for all movers within the EU, independently of their economic status (ibid. 4). Silvia Gastaldi reminds us that these two visions, a priori incompatible, are cohabiting together in the field of EU intra-mobility. This cohabitation makes the situation complex and not transparent (ibid. 5).

First, the EU citizenship's inability to overcome categorizations of EU citizens comes from its specificity and narrowness. It does not indeed reach the scope of a national citizenship. It is just an additional citizenship, that depends on the existence of a first national citizenship. It cannot exist independently from national citizenships. And only national citizenship from one member state of the EU can lead to EU citizenship.

Secondly, it is only in the sphere of rights that EU citizenship seems well advanced, as the other levels of citizenship (status, duties, identity) are less developed (Shaw 2018: 5). And even in this more developed field, the results are still weak, as the number of rights deriving from EU citizenship is limited. Article 20 TFEU deals only with few aspects of the life of the EU citizen: the right to move and reside within the territory of the member states, the right to vote and to stand as candidates in elections for the European Parliament, the right to enjoy the protection of the diplomatic and consular authorities of any member state, the right to petition the European Parliament and to address the institutions and advisory bodies of the Union in any of the Treaty languages. Moreover, Article 20 TFEU clearly states that the rights linked to EU citizenship are conditional: indeed, these rights shall be exercised in accordance with the conditions and limits defined by the Treaties and by the measures adopted thereunder. 
Derogations exist and are largely used by member states even if they should be interpreted strictly while the fundamental right of freedom of movement should be interpreted widely. ${ }^{19}$

Thirdly, EU citizenship does not ensure to EU citizens the benefit of the generosity and the solidarity of the host member states. EU mobile citizens are not equal to nationals of the host member states, except for the workers. At the national level, member states are obliged to take care of their poor citizens and to provide them access to social assistance. Even if the CJEU seemed, for a while, to confer social assistance to economically inactive EU citizens, on the ground of their EU citizenship, this time is now over. EU citizenship cannot prevent differentiations grounded on the economic status of the migrant: residential and social rights are limited for economically inactive migrants. Thus we can talk of a merely 'market' citizenship or a 'self-sufficiency citizenship'.

Finally, EU citizenship is not able to guarantee EU citizens the application of the droit pénal de l'ami (D’Ambrosio 2010: 8). It allows the expulsion of mobile EU citizens from their host member states while national states are not allowed to expel their own citizens. This distinction is fundamental and creates a big gap between both national and EU citizenships. The introduction of an EU citizenship by the Maastricht Treaty and its coexistence with expulsion brought a series of intellectual and theoretical problems that remain unresolved. Expulsion is the ultimate dividing line between the citizen and the alien - who has the right to enter and who is excluded. It is the antithesis of citizenship in liberal democracies (Mantu 2018: 5).

19 Cases C-139/85 - Kempf, paragraph 13; C-33/07 - Jipa, paragraph 23.
Because of all its shortcomings and weaknesses, EU citizenship is not able to correspond to member states' categorization of EU citizens. Its insufficient content of rights, its lack of protection measures, its recent abandonment by the CJEU and its derivation from national citizenship must be dealt with if EU citizenship is to play a bigger role in the future.

\section{Conclusion}

Categorization of EU migrants has existed since the beginning of the European project and is still valid today. This categorization of the EU is not supposed to be based on the nationality of EU migrants as such discrimination is forbidden by Article 18 TFEU. The main categorization derives from an economic criterion, that separates EU migrants into economically active and inactive citizens (Gastaldi 2018: 587-93). The first category benefits from total freedom of movement and residence and from equality of treatment. The second category has a conditional right to move and reside as well as limited social rights on the territory of the member states. This legal categorization of EU migrants serves member states, that can protect their national interests. EU law provides them indeed with effective instruments against any abuse of rights or fraud (Article 35, Directive $2004 / 38 / E C$ ) or against any threat to public policy or security (Article 27) or against any unreasonable burden on their social security system (Article 14). This economic criterion has been with time counterbalanced by the taking into account of more personal criteria such as family life and the hazards of life of the EU migrant. But the most significant step was certainly the CJEU's attempt to elevate EU citizenship as the fundamental status of nationals of EU member States, enabling the conferral of supplementary rights to economic- 
ally inactive EU citizens, despite the existence of a restrictive legislation. ${ }^{20}$ It seems that the recent economic crisis has not only made this attempt disappear but it has also led some member states to wish for stricter categorization of EU migrants. The existing legal categorization of EU migrants deriving from Directive 2004/38/EC, already restrictive towards economically inactive EU citizens, seems insufficient today. Some host member states are willing to add supplementary categorizations, very often based on the criterion of poverty. Indeed, there is a clear fear of poor EU migrants, demonstrated by anti-migration political discourses and actions and expulsion measures. ${ }^{21}$

Deepening existing legal categorization of EU migrants does not serve the concepts of European Citizenship, nor of European integration. Indeed, EU citizenship aims to unite EU citizens to overcome categorization by nationality but also to promote EU objectives and values such as solidarity, combatting social disorder and discrimination and an ever closer union amongst the people of Europe. Similarly, European integration aims to harmonize, to balance national fields and by doing so, to eliminate national categorizations. The

20 This attempt started with the case Martinez Sala where the Court of Justice recognized that economically inactive EU citizens on the move could benefit from equality of treatment with nationals of the host member state in all fields of application of EU treaties (C-85/96).

21 For example, Austria decided to lower family social assistance to EU movers from Slovakia and Czech Republic in early 2019 (Idnes 2019a). Some member states are even expelling more EU citizens than third-country nationals. It is the case in Austria which has been accused by Czech media of expelling more Slovaks and Czechs than Nigerian citizens (Idnes 2019b). legal categorization of EU migrants allows member states to keep their sovereign power regarding the choice of the migrant allowed to stay and benefit from their generosity. On the other hand, categorization of EU migrants by member states, in practice, targeting poor migrants and conducing to their expulsion, is much more damaging, as it is not based upon objective legal criteria but only on subjective national criteria, most of the time not legally grounded.

The ongoing process of recategorization of EU migrants, between those who are welcome and those who are not, clearly shows the weaknesses of EU citizenship and of the EU project. EU citizenship, no longer used by the CJEU as a ground provider of rights in matters of freedom of movement, is nowadays unable to overcome the restrictive approaches towards economically inactive EU migrants. The loss of significance of EU citizenship and of EU values and objectives is worrying and makes one fear steps backwards for EU intra-mobility. That is why 'a more just EU can only follow from rethinking what role the vulnerable groups, such as economically inactive and dependent EU citizens, play in the overall project of European integration' (Neuvonen 2016: 190).

Solange Maslowski is a senior researcher affiliated to the Centre for Comparative Law of the Faculty of Law at Charles University in Prague, posted for two years at the Centre of Migration

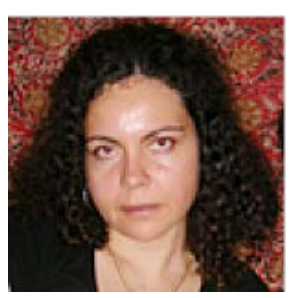
Research of the University of Warsaw. She holds a PhD in European Law from the University of Toulouse 1 (France) and from the Faculty of Law of Charles University (Czech Republic). During her doctoral studies, she worked on the field of the harmonization of law, focusing on the reprisal of the acquis communautaire by the Czech Republic. She is now researching the field of the right of 
EU citizens to move and reside freely within the territory of the Member States. She is currently working on a research project on 'The Future of Freedom of Movement for Economically Inactive EU Citizens funded by the Czech Ministry of Education, Youth and Sports' (International Mobility of Research Employees-MSCA-IF, Operational Programme Research, Development and Education).

This article has been supported by the project c. CZ.02.2.69/0.0/0.0/17_050_0008466from the Czech Ministry of Education, Youth and Sports (International Mobility of Research Employees-MSCA-IF, Operational Programme Research, Development and Education).

\section{Sources}

\section{Council of the European Union}

Consolidated version of the Treaty on the Functioning of the European Union, Official Journal of the European Communities, C326, 26.10.2012, <http://data.europa.eu/ eli/treaty/tfeu_2012/oj>

Council Directive 68/360/EEC of 15 October 1968 on the abolition of restrictions on movement and residence within the Community for workers of member states and their families (CELEX: 31968Lo360), Official Journal of the European Communities, L257, 19.10.1968 (Publications Office of the European Union), <http://data.europa.eu/ eli/dir/1968/360/oj>

Council Directive 90/365/EEC of 28 June 1990 on the right of residence for employees and self-employed persons who have ceased their occupational activity (CELEX: 31990L0365), Official Journal of the European Communities, L180, 13.7.1990 (Publications Office of the European Union), $<$ http://data.europa.eu/eli/dir/1990/365/ oj>

Council Directive 90/366/EEC of 28 June 1990 on the right of residence for students (CELEX: 31990Lo366), Official Journal of the European Communities, L180, 13.7.1990 (Publications Office of the European Union), <http://data.europa.eu/eli/ $\operatorname{dir} / 1990 / 366 / o j>$

Council Directive 93/96/EEC of 29 October
1993 on the right of residence for students (CELEX: 31993Loo96), Official Journal of the European Communities, L317, 18.12.1993 (Publications Office of the European Union), <https://eur-lex.europa.eu/ eli/dir/1993/96/oj>

Directive 2004/38/EC of the European Parliament and of the Council of 29 April 2004 on the right of citizens of the Union and their family members to move and reside freely within the territory of the member states amending Regulation (EEC) No 1612/68 and repealing Directives 64/221/ EEC, 68/360/EEC, 72/194/EEC, 73/148/ EEC, 75/34/EEC, 75/35/EEC, 90/364/ EEC, 90/365/EEC and 93/96/EEC (CELEX: 32004Loo38), Official Journal of the European Communities, L158, 30.4.2004 (Publications Office of the European Union), $<$ http://data.europa.eu/eli/dir/2004/38/oj>

\section{Court cases of the Court of Justice}

\section{of the European Union}

C-33/07 - Jipa. Judgment of the Court (First Chamber) of 10 July 2008, Ministerul Administraţiei şi Internelor - Direcţia Generală de Paşapoarte București v Gheorghe Jipa (CELEX: 62007CJo033), European Court Reports 2008-I-05157, <https:// eur-lex.europa.eu/legal-content/EN/ ALL/?uri=CELEX\%3A62007CJo033>

C-67/14 - Alimanovic. Judgment of the Court (Grand Chamber) of 15 September 2015, Jobcenter Berlin Neukölln v Nazifa Alimanovic and Others (CELEX: 62014CJ0067), Digital Reports, <https:// eur-lex.europa.eu/legal-content/EN/ $\mathrm{TXT} /$ ?uri=CELEX\%3A62014CJ0o67>

C-85/96 - Martínez Sala v Freistaat Bayern. Judgment of the Court of 12 May 1998, María Martínez Sala v Freistaat Bayern (CELEX: 61996CJoo85), European Court Reports 1998-I-02691, <https:// eur-lex.europa.eu/legal-content/FI/ TXT/?uri=CELEX:61996CJoo85>

C-127/08 - Metock et al. Judgment of the Court (Grand Chamber) of 25 July 2008, Blaise Baheten Metock, Hanette Eugenie Ngo Ikeng, Christian Joel Baheten, Samuel Zion Ikeng Baheten, Hencheal Ikogho, Donna Ikogho, Roland Chinedu, Marlene Babucke Chinedu, Henry Igboanusi, Roksana 
Batkowska v Minister for Justice, Equality and Law Reform (CELEX: 62008CJ0127), European Court Reports 2008-I-06241, $<$ https://eur-lex.europa.eu/legal-content/ $\mathrm{EN} / \mathrm{ALL} /$ ?uri=CELEX\%3A62008CJ0127>

C-139/85 - Kempf. Judgment of the Court of 3 June 1986, R. H. Kempf v Staatssecretaris van Justitie (CELEX: 61985CJo139), English Special Edition VIII 00655, <https:// eur-lex.europa.eu/legal-content/FI/ ALL/?uri=CELEX:61985CJo139>

C-184/99 - Grzelczyk. Judgment of the Court of 20 September 2001, Rudy Grzelczyk v Centre public d'aide sociale d'Ottignies-Louvain-la-Neuve (CELEX: 61999Jo184), European Court Reports 2001-I-06193<https:// eur-lex.europa.eu/LexUriServ/LexUriServ. do?uri=CELEX:61999CJo184:EN:HTML>

C-299/14 - García-Nieto et al. Judgment of the Court (First Chamber) of 25 February 2016, Vestische Arbeit Jobcenter Kreis Recklinghausen v Jovanna García-Nieto, Joel Peña Cuevas, Jovanlis Peña García, Joel Luis Peña Cruz (CELEX: 62014CA0299), Official Journal of the European Communities, C145, 25.4.2016, pp. 7-8 (Publications Office of the European Union), $<$ https://eur-lex.europa.eu/legal-content/ FI/TXT/?uri=CELEX:62014CA0299>

C-308/14 - Commission v United Kingdom. Judgment of the Court (First Chamber) of 14 June 2016, European Commission $\mathrm{v}$ United Kingdom of Great Britain and Northern Ireland (CELEX: 62014CA0308), Official Journal of the European Communities, $\mathrm{C}_{305}$, 22.8.2016, p. 4 (Publications Office of the European Union), <https:// eur-lex.europa.eu/legal-content/EN/ $\mathrm{TXT} /$ ?uri=CELEX\%3A62014CA0308>

C-333/13 - Dano. Judgment of the Court (Grand Chamber) of 11 November 2014, Elisabeta Dano and Florin Dano v Jobcenter Leipzig (CELEX: 62013CJ0333), Digital Reports, $<$ https://eur-lex.europa.eu/legal-content/ $\mathrm{EN} / \mathrm{SUM} /$ ?uri=CELEX\%3A62013CJ0333>

C-482/01 and C-493/01. Judgment of the Court (Fifth Chamber) of 29 April 2004, Georgios Orfanopoulos and Others (C-482/91/ and Raffaele Oliveri (C-493/01) v Land BadenWürttemberg (CELEX: 62001CJ0482), European Court Reports 2004-I-05257, $<$ https://eur-lex.europa.eu/legal-content/ FI/TXT/?uri=CELEX:62001CJ0482>

\section{Bibliography}

Azoulai, Loic, 2014. 'The (mis)construction of the European individual: two essays on Union citizenship law', EUI Law, 2014/14, $<$ http://hdl.handle.net/1814/33293>

Carrera, Serge, 2014. 'The framing of the Roma as abnormal EU citizens: assessing European politics on Roma evictions and expulsions in France,', The Reconceptualization of European Union Citizenship, ed. Elspeth Guild, Cristina Gortázar Rotaeche, and Dora Kostakopoulou (Leiden, Brill Nijhoff), pp. 33-63

D’Ambrosio, Lucas, 2010. 'Quand l'immigration est un délit', la vie des idées.fr, 30.11.2010, <https://laviedesidees.fr/IMG/ pdf/20101130_immigration.pdf > (accessed 15.2.2019)

ERGO Network, 2019. 'Unprecedented police action against Roma Travellers community in Belgium, ERGO Network, 10.5.2019, $<$ http://ergonetwork.org/2019/05/policeaction-against-roma-travellers-community-in-belgium/> (accessed 16.5.2019)

ERRC, 2019. 'Roma win first-ever judgement of "institutional racism" in Europe', European Roma Rights Centre, 17.4.2019, <http:// www.errc.org/press-releases/roma-winfirst-ever-judgement-of-institutional-racism-in-europe > (accessed 15.5.2019)

Flash Eurobarometer 365. European Union Citizenship, Flash Eurobarometer 365 (European Commission, Directorate-General Justice, 2013), <http://ec.europa.eu/commfrontoffice/publicopinion/flash/fl_365_ en.pdf $>$ (accessed 10.1.2019)

Gastaldi, Silvia, 2013. Citoyenneté de l'Union et libre circulation : du critère économique au statut unique, Dossiers de droit européen, 28 (Basel, Schulthess Verlag)

Guild, Elspeth, Steve Peers, and Jonathan Tomkin, 2014. The EU Citizenship Directive (Oxford University Press)

Idnes, 2019a. 'Rakousko snižuje cizím rodičům dávky podle pobytu, Češi a Slováci se bouří, 1.2.2019, <https://www.idnes.cz/zpravy/ zahranicni/socialni-davky-podporadeti-cesi-slovaci-rakousko-soud> (accessed 3.2.2019)

- - 2019b. 'Rakousko umí vyhoštovat spíš Evropany. Mnohem častěji Slováky než Nigerijce', iDNES.cz / Zpravodasjství, 4.2.2019, $<$ https://www.idnes.cz/zpravy/zahranicni/ 
rakousko-slovaci-pristehovalci-vyhostenimigrace-migranti.A190204_151049_zahranicni_chtl> (accessed 15.3.2019)

Joint letter 2013. Joint letter from the Federal Minister of the Interior of Austria, the Federal Minister of the Interior of Germany, the Minister for Immigration of the Netherlands and the Secretary of State for the Home Department of United Kingdom to Mr. Alan Shatter, Minister for Justice and Equality, President of the European Council for Justice and Home Affairs, with a copy to responsible Ministers of EU MS; Commissioners Reding, Malmstrom and Andor, 2013, <http://docs.dpaq.de/3604130415_letter_to_presidency_final_1_2. pdf $>$ (accessed 15.1.2019)

Lafleur, Jean-Michel, and Mikolaj Stanek, 2017. Lessons from the Migration of EU Citizens in Times of Crisis in South-North Migration of EU Citizens in Times of Crisis, IMISCOE Research Series (Springer Open)

Lhernould, Jean-Philippe, 2011. 'Prestations sociales : les Roms roumains et bulgares ne sont pas des sous-citoyens de l'Union européenne', Abécédaire des discriminations : six ans de délibération de la Halde (Documentation française)

LaLibre.be, 2013. 'Les Roms? Des souscitoyens européens', LaLibre.be, 2.11.2013, $<$ https://www.lalibre.be/actu/international/ les-roms-des-sous-citoyens-europeens527482b7357046af569ee688> (accessed 15.1.2019)

Mantu, Sandra (ed.), 2018. Expulsion and EUCitizenship, Nijmegen Migration Law Working Papers Series, 2017/02 (Nijmegen, Radboud University) <https://repository.ubn.ru.nl/ bitstream/handle/2066/179152/179152. pdf? sequence $=1>($ accessed 15.5.2019)

Maslowski, Solange, 2015. 'The expulsion of European Union citizens from the host member state: legal grounds and practices', Central and Eastern European Migration Review, 4(2), December, pp. 61-85, $<$ http://ceemr.uw.edu.pl/sites/default/files/ CEEMR_Vol_4_No_2_Maslowski_The_ Expulsion_of_European_Union_Citizens. pdf $>$ (accessed 15.5.2019)

Minderhoud, P. E., 2018. Social Assistance for Economically Inactive EU Citizens in the Member States, Nijmegen Migration Law
Working Papers Series, no. 2018/03 (Radboud University Nijmeged), <https:// repository.ubn.ru.nl/bitstream/handle $/ 2066 / 194560 / 194560 . p d f$ ? sequence $=1>$

Neuvonen, Paivi Johanna, 2016. Equal Citizenship and its Limits in EU Law: We the Burden? (London and Portland OR, Hart Publishing).

Parnell-Berry, Bel, and Alan Lawton, 2018. 'Citizenship for all? Mobility and the "right" way to live', Administrative Theory and Praxis, 41(1), pp. 35-59, <https://www. tandfonline.com/doi/full/10.108o/1084180 6.2018.1512335>

Shaw, Jo, 2018. 'EU citizenship: still a fundamental status?', Debating European Citizenship, ed. Rainer Bauböck, IMISCOE Research Series (Springer Open), pp. 43-6, <https://link.springer.com/content/ pdf/10.1007\%2F978-3-319-89905-3.pdf> (accessed 15.1.2019)

The Conversation, 2019. 'Why are Roma people being attacked in France? The Conversation, 7.4.2019, <https://theconversation.com/ why-are-roma-people-being-attacked-infrance-115030> (accessed 1.6.2019) 